\title{
Olsenella umbonata sp. nov., a microaerotolerant anaerobic lactic acid bacterium from the sheep rumen and pig jejunum, and emended descriptions of Olsenella, Olsenella uli and Olsenella profusa
}

\author{
Correspondence \\ Mareike Kraatz \\ mkraatz@zedat.fu-berlin.de
}

\author{
Mareike Kraatz, ${ }^{1}$ R. John Wallace ${ }^{2}$ and Liselott Svensson ${ }^{3}$ \\ ${ }^{1}$ Institute of Animal Nutrition, Faculty of Veterinary Medicine, Free University Berlin, D-14195 \\ Berlin, Germany \\ ${ }^{2}$ University of Aberdeen, Rowett Institute of Nutrition and Health, Aberdeen AB21 9SB, UK \\ ${ }^{3}$ Culture Collection University of Gothenburg (CCUG), Department of Clinical Bacteriology, SE-413 \\ 46 Gothenburg, Sweden
}

Strain A2 is an anaerobic, variably Gram-stain-positive, non-spore-forming, small and irregularly rod-shaped bacterium from the ruminal fluid of a sheep that has been described informally as a representative of 'Olsenella (basonym Atopobium) oviles'. Three phenotypically similar bacterial strains (lac15, lac16 and lac31 $1^{\top}$ ) were isolated in concert with Veillonella magna lac $18^{\top}$ from the mucosal jejunum of a pig. A phylogenetic analysis based on 16S rRNA gene sequences revealed that strains $A 2$, lac15, lac16 and lac $31^{\top}$ formed a genetically coherent group (100\% interstrain sequence similarity) within the bigeneric Olsenella-Atopobium branch of the family Coriobacteriaceae, class Actinobacteria. This group was most closely related to the type strains of the two recognized Olsenella species, namely Olsenella uli (sequence similarity of $96.85 \%$ ) and Olsenella profusa (sequence similarity of $97.20 \%$ ). The sequence similarity to the type strain of Atopobium minutum, the type species of the genus Atopobium, was $92.33 \%$. Unlike those of O. uli and O. profusa, outgrown colonies of strains $A 2$, lac 15 , lac 16 and lac $31^{\top}$ were opaque and greyish-white with an umbonate elevation on solid culture media. The four novel strains were characterized as being well-adapted and presumably indigenous to the gastrointestinal tract of homoeothermic vertebrates: they were mesophilic, microaerotolerant, neutrophilic and acidotolerant, bile-resistant, mucin-utilizing and markedly peptidolytic lactic acid bacteria. The results of DNA-DNA hybridizations, cellular fatty acid analysis and other differential phenotypic (physiological and biochemical) tests confirmed that strains $A 2$, lac15, lac16 and lac31 ${ }^{\top}$ represent a novel species of the genus O/senella. On the basis of the genotypic and phenotypic results, we therefore describe Olsenella umbonata sp. nov., with lac31 ${ }^{\top}$ (=CCUG $58604^{\top}$ $=\mathrm{DSM} 22620^{\top}=\mathrm{JCM} 16156^{\top}$ ) as the type strain and A2 (=CCUG $58212=\mathrm{DSM} 22619=\mathrm{JCM}$ 16157) as an additionally available reference strain. Also, based on our data, we propose emended descriptions of the genus O/senella and the species O/senella uli and O/senella profusa.
The genera Olsenella Dewhirst et al. 2001, Atopobium Collins and Wallbanks 1993 and Bifidobacterium OrlaJensen 1924 constitute the high-G $+\mathrm{C}$-content group of the

Abbreviations: ME, minimum-evolution; MP, maximum-parsimony; $\mathrm{NJ}$, neighbour-joining; URAS, unreduced aerobically sterilized.

The GenBank/EMBL/DDBJ accession numbers for the 16S rRNA gene sequences of strains $A 2$, lac 15 , lac 16 and $\operatorname{lac} 31^{\top}$ are respectively AJ251324, FN178461, FN178462 and FN178463.

Four supplementary figures and two supplementary tables are available with the online version of this paper. lactic acid bacteria sensu lato (Inês et al., 2008). The bacteria in this group are defined as members of the class Actinobacteria meeting the core phenotypic criteria of OrlaJensen (1919): they are Gram-stain-positive, non-motile, non-spore-forming rods or cocci that ferment carbohydrates to predominant (Olsenella, Atopobium) or important (Bifidobacterium) amounts of lactic acid.

At the time of writing, the genus Olsenella comprises two species with validly published names: Olsenella uli Dewhirst et al. 2001 (basonym Lactobacillus uli Olsen et al. 1991) and Olsenella profusa Dewhirst et al. 2001 (previously desig- 
nated Eubacterium group D52 by W. E. C. Moore and L. V. H. Moore). These species were based on strains from gingival and subgingival sites in humans with periodontitis. A third species with one strain (A2) from the rumen of a sheep had been informally named 'Atopobium oviles' (Eschenlauer et al., 2002) and was renamed 'Olsenella oviles' by Dewhirst et al. (2001).

According to Dewhirst et al. (2001), the human oral cavity is the main habitat and the bovine rumen a likely habitat of the olsenellae. Isolates of $O$. uli and O. profusa are regularly recovered from disease sites in the human mouth (Munson et al., 2002, 2004; Hooper et al., 2006) and sometimes from blood of humans with local oral or gastrointestinal infections (Lau et al., 2004; Bahrani-Mougeot et al., 2008). Olsenellae are found in the healthy (Ozutsumi et al., 2005; Cho et al., 2006; Hernandez et al., 2008) and acidotic (Tajima et al., 2000) bovine rumen. Moleculargenetic studies have also reported the detection of Olsenella-related clones in the gastrointestinal tracts of humans (Martinez-Medina et al., 2006; Khachatryan et al., 2008; Krogius-Kurikka et al., 2009), pigs (Leser et al., 2002; Tsukahara \& Ushida, 2002; Dowd et al., 2008), wallabies (Chhour et al., 2008) and chickens (Lu et al., 2003) and in diverse anaerobic environmental sites (Bowman et al., 2006; Wongtanet et al., 2007; Weiss et al., 2008; Rivière et al., 2009). This indicates that the habitats of the olsenellae generally comprise the oral cavity and gastrointestinal tract of homoeothermic vertebrates and that non-animal habitats also exist.

Strain A2 was isolated from the ruminal fluid of a sheep at the Rowett Institute of Nutrition and Health in 1994. The methods and results of isolation, $16 \mathrm{~S}$ rRNA gene sequencebased identification and initial phenotypic characterization were described in detail by Eschenlauer et al. (2002). Strains lac15, lac16 and lac $31^{\mathrm{T}}$ were isolated from the mucosal jejunum of a pig that also harboured $l a c 18^{\mathrm{T}}$, the type strain of Veillonella magna, at the Institute of Animal Nutrition in 2007. The methods of isolation and initial $16 \mathrm{~S}$ rRNA gene sequence-based phylogenetic analysis using primers $27 \mathrm{f}$ and $1492 \mathrm{r}$ were described by Kraatz \& Taras (2008).

Further genotypic studies included PCR amplification and direct sequencing of the $16 \mathrm{~S}$ rRNA gene using the Coriobacteriaceae-suited primer pair $\mathrm{C} 75$ and $\mathrm{C} 90$ (Dewhirst et al., 2001). DNA was extracted from cells with a NucleoSpin Tissue kit (Macherey-Nagel). PCR was performed in a T1 Thermocycler (Biometra) using a HotStarTaq Master Mix kit (Qiagen). PCR products were purified with a High Pure PCR product purification kit (Roche). Sequencing was performed commercially by primer-walking (Eurofins MWG Operon) with C75 and C90 as starting primers. Nearly full-length (1428-1434 bp) $16 \mathrm{~S}$ rRNA gene sequences of the four novel strains and of O. uli DSM $7084^{\mathrm{T}}$, O. profusa strains DSM $13989^{\mathrm{T}}$, CCUG $45371^{\mathrm{T}}$ and CCUG 45372 and Atopobium minutum DSM $20586^{\mathrm{T}}$ were obtained and submitted to EMBL (accession nos AJ251324 and FN178461-FN178468). Phylogenetic sequence analysis was conducted using the online Ribosomal Database Project II classification algorithm (Cole et al., 2009), the online NCBI BLASTN algorithm (Johnson et al., 2008), MEGA software version 4.1 (Tamura et al., 2007) and CONSENSE from the PHYLIP software package version 3.69 (Felsenstein, 2010). In MEGA4, alignments of the newly determined sequences and 14 related sequences retrieved from GenBank were carried out using the ClUSTAL w tool (Thompson et al., 1994). Pairwise evolutionary distances were computed by using the maximum composite likelihood method (Tamura et al., 2004) with the Tamura-Nei nucleotide substitution model (Tamura \& Nei, 1993) after complete deletion of positions with gaps or missing data. Phylogenetic trees were inferred using maximum-parsimony (MP) (Fitch, 1971), neighbour-joining (NJ) (Saitou \& Nei, 1987) and minimumevolution (ME) (Rzhetsky \& Nei, 1992) methods. The bootstrap method (Felsenstein, 1985) was always used with 1000 replicates to test the statistical reliability of the trees. Genomic DNA-DNA reassociation analysis was carried out using hybridization protocols described by Urdiain et al. (2008). Labelled reference DNA of strain lac $31^{\mathrm{T}}$ or $O$. profusa CCUG $45371^{\mathrm{T}}$ was hybridized to unlabelled target DNA of strain A2, O. profusa CCUG 45372 and O. uli CCUG $31166^{\mathrm{T}}$ (as well as to homologous unlabelled DNA). Each hybridization mixture contained 150 ng reference DNA and $15 \mu \mathrm{g}$ target DNA in a total volume of $72 \mu \mathrm{l}$. The mixtures were incubated for $16 \mathrm{~h}$ at $71{ }^{\circ} \mathrm{C}$ (i.e. at $30{ }^{\circ} \mathrm{C}$ below the melting-point temperature of DNA with a $\mathrm{G}+\mathrm{C}$ content of 63-64 mol\% reported by Dewhirst et al., 2001).

The results of $16 \mathrm{~S}$ rRNA gene sequence-based phylogenetic analysis revealed that the strains lac15, lac16, lac $31^{\mathrm{T}}$ and A2 belonged to the genus Olsenella and formed a genetically coherent group ( $100 \%$ interstrain sequence similarity) within the bigeneric Olsenella-Atopobium branch of the family Coriobacteriaceae, class Actinobacteria (Fig. 1). O. uli and $O$. profusa were the most closely related recognized species (sequence similarities of 96.85 and $97.20 \%$ to the respective type strains), and the type strain of $A$. minutum, the type species of the genus Atopobium, was a more distant relative $(92.33 \%)$. The sequence similarity with respect to Coriobacterium glomerans, the type species of the Coriobacteriaceae, was $88.30-88.31 \%$. The genetic distinctness of the novel group within the bigeneric OlsenellaAtopobium branch was supported by bootstrap values of 88-92\% (mean, 90\%; $n=10$ ) in the MP consensus tree (Fig. 1). Bootstrap values were lower in the $\mathrm{NJ}$ and $\mathrm{ME}$ analyses [ $49-51$ and $51-53 \%$ (means, 50 and $52 \% ; n=10$ ), respectively], although they still confirmed the branching pattern of the MP tree (Supplementary Fig. S1, available in IJSEM Online). The results of DNA-DNA hybridization are presented in Supplementary Table S1. Relative reassociation of DNA of strain $\operatorname{lac} 31^{\mathrm{T}}$ was maximal $(102.5 \%)$ with DNA of strain A2 and approximately $50 \%$ with respect to DNA of strains of O. uli $(47.3 \%)$ and O. profusa (50.2 and $51.9 \%$ ). DNA of O. profusa CCUG 
$45371^{\mathrm{T}}$ exhibited less than $50 \%$ relative reassociation with DNA of strains $\operatorname{lac} 31^{\mathrm{T}}$ and A2 (32.7 and $40.0 \%$, respectively). Altogether, the DNA-DNA relatedness between the novel strains lac $31^{\mathrm{T}}$ and $\mathrm{A} 2$ and recognized strains of $O$. uli and O. profusa was clearly below the $70 \%$ cut-off value recommended for species delineation (Wayne et al., 1987; Stackebrandt et al., 2002; Achtman \& Wagner, 2008). As indicated by the results of $16 \mathrm{~S}$ rRNA gene sequence-based phylogenetic analysis, the novel strains were related very closely to each other and were related more closely to O. profusa than to O. uli.

Phenotypic studies were performed using the following culture media: modified peptone-yeast extract-glucose (PYG) medium (DSMZ medium 104 including salt solution 104; http://www.dsmz.de) as the standard, unreduced PYG broth (DSMZ medium 104 without cysteine hydrochloride), peptone-yeast extract (PY) broth (DSMZ medium 104 without glucose), M2 liquid medium containing clarified rumen fluid (Hobson, 1969), fastidious anaerobe agar (FAA) [FAA (Lab M) plus $5 \%$ defibrinated horse blood (Oxoid)], blood agar [blood agar base no. 2 (Lab M) plus $5 \%$ defibrinated horse blood (Oxoid)], an unsupportive basal medium (UBM), porcine gastric mucin (PGM) agar, porcine gastric mucus-mucosa (PGMM) agar and porcine jejunal mucus-mucosa (PJMM) agar; the last three media contained UBM [DSMZ medium 104 without PYG and meat extract and including $\left(1^{-1}\right) 3.0 \mathrm{~g} \mathrm{NaCl}$, $0.18 \mathrm{~g} \mathrm{MgSO}_{4} .7 \mathrm{H}_{2} \mathrm{O}$ and $0.01 \mathrm{~g} \mathrm{FeSO}_{4} .7 \mathrm{H}_{2} \mathrm{O}$, together with $1 \mathrm{ml}$ trace element solution and 0.2 vitamin solution described by Kraatz \& Taras (2008)] supplemented with $1 \%(\mathrm{w} / \mathrm{v})$ mucin from porcine stomach (type III; Sigma) (PGM; pH 7) or mucus and mucosa from the stomachs (PGMM; pH 5) or jejuna (PJMM; pH 6.5) of healthy pigs. Unless otherwise stated, cultivations were performed at $37{ }^{\circ} \mathrm{C}$. Anaerobic [i.e. anoxic, $\mathrm{CO}_{2}$-enriched $(18 \% \mathrm{v} / \mathrm{v})$ ], microaerobic [i.e. oxygen-reduced (5-7\% v/v) and $\mathrm{CO}_{2}$ enriched $(8-10 \% \mathrm{v} / \mathrm{v})]$ and aerobic cultivations on agar media were performed in anaerobic jars using Anaerocult
A gas packs, Anaerocult C gas packs (both from Merck) and no gas packs, respectively. Anaerobic and microaerobic cultivations in broth media were respectively performed in anaerobically sterilized (nitrogen-purged) and aerobically sterilized (unpurged) rubber-stoppered glass tubes $(110 \times 15 \mathrm{~mm})$. Growth in broth media was monitored by measuring the $\mathrm{OD}_{600}$ with an Ultrospec 2000 spectrophotometer (Pharmacia Biotech). Studies were usually carried out with five (analyses using API kits) or three (other analyses) repetitions for each strain.

Morphology was studied using light and scanning electron microscopy with cells grown anaerobically on FAA and PYG agar for $48 \mathrm{~h}$ and 7 days and on PGM, PGMM and PJMM agar for 14 days. Cell size was determined from digital scanning electron micrographs using the measurement tool of the Adobe Photoshop CS4 Extended software. Morphological studies and studies on motility, spore formation, cytochrome oxidase activity and nitrate reduction were conducted as described previously (Kraatz \& Taras, 2008). The oxygen relationship was determined using anaerobic cultures on PYG agar and in PYG broth, microaerobic cultures on PYG agar and in unreduced aerobically sterilized (URAS) PYG broth and aerobic cultures on PYG agar. Oxygen levels in the culture media were assessed by adding $1 \mathrm{mg}$ resazurin sodium salt (Sigma) $1^{-1}$ as redox indicator (orange or red colour indicative of the reduced or oxidized form of resazurin in anaerobic or microaerobic and aerobic PYG medium). Referring to the approach of Karakashev et al. (2003), assessment of growth and changed redox status in microaerobic URAS liquid media with resazurin allows further differentiation of obligately anaerobic bacteria (Winn et al., 2006) into microaerotolerant (moderately obligate) anaerobes and strictly obligate anaerobes. URAS PYG broth cultures of the novel strains and strains of $O$. uli and O. profusa were prepared as $7.5 \mathrm{ml}$ volumes with an initial $\mathrm{OD}_{600}$ of $0.03-0.18$ (mean, $0.09 ; n=24$ ) above that of the uninoculated controls. Analyses of growth at

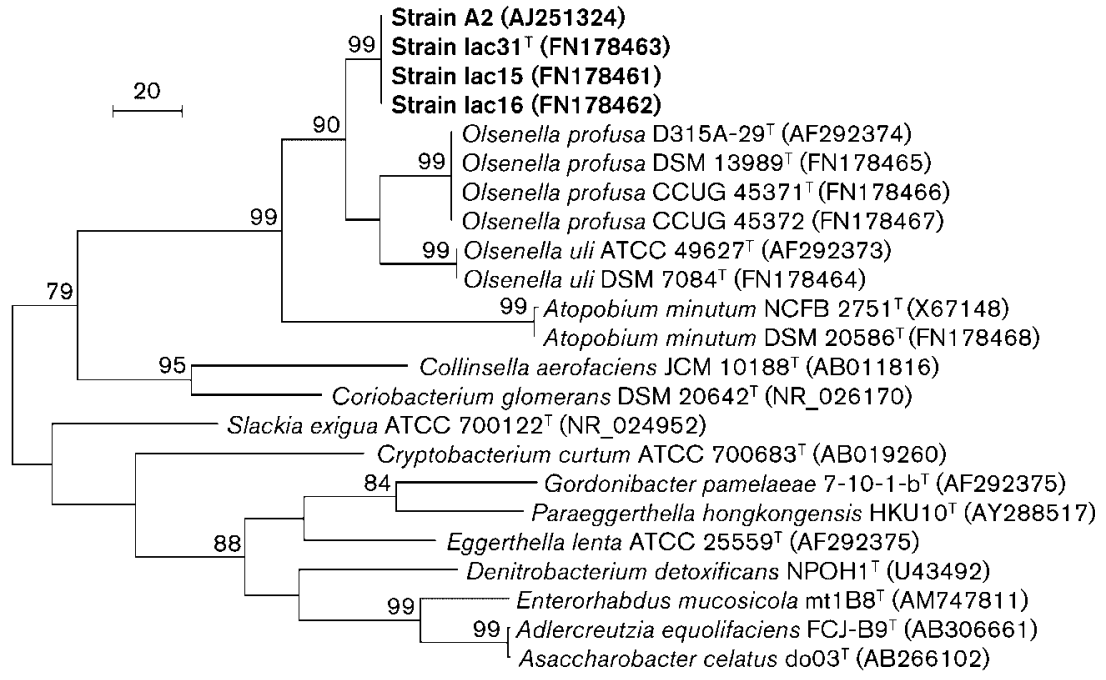

Fig. 1. Maximum-parsimony tree reconstructed using partial 16S rRNA gene sequences showing the phylogenetic relationship of strains lac15, lac16, lac $31^{\top}$ and $A 2$ to other members of the bigeneric Olsenella-Atopobium branch and the family Coriobacteriaceae, including all type species. The tree is the unrooted consensus of 1000 bootstrap replicates. Bootstrap percentages greater than $70 \%$ are given at branch points. Bar, 20 base changes between nodes. 
different temperatures $\left(21,30,37\right.$ and $\left.45{ }^{\circ} \mathrm{C}\right)$ and $\mathrm{pH}$ (initial $\mathrm{pH}$ 2.0-9.5 at intervals of $0.5 \mathrm{pH}$ units), growth resistance tests with $20 \%$ bile (Jousimies-Somer et al., $2002)$ or $6.5 \%(\mathrm{w} / \mathrm{v}) \mathrm{NaCl}$ and growth stimulation tests with $0.1 \%(\mathrm{v} / \mathrm{v})$ Tween 80 or $0.5 \%(\mathrm{w} / \mathrm{v})$ L-arginine were carried out using anaerobic cultures in PYG broth. Production of hydrogen sulfide from meat peptone or Lcysteine was studied using anaerobic cultures in UBM broth enriched with trypticase peptone and glucose and supplemented with $0.5 \mathrm{~g}$ ferric ammonium citrate $\mathrm{l}^{-1}$ and $10 \mathrm{~g}$ meat peptone or $0.73 \mathrm{~g} \mathrm{~L}$-cysteine $\mathrm{l}^{-1}$. Production of gas from $1 \%(\mathrm{w} / \mathrm{v})$ glucose was examined using anaerobic stab cultures in PYG agar deeps following the method for anaerobes of Smibert \& Krieg (1994). For analysis of hydrogen peroxide production (Juárez Tomás et al., 2004), cells were grown on PYG agar without resazurin and supplemented with $0.01 \mathrm{~g}$ horseradish peroxidase (type VIA; Sigma) $\mathrm{l}^{-1}$ and $20 \mathrm{ml}$ TMB (3,3',5, $5^{\prime}$-tetramethylbenzidine; Sigma) solution [ $25 \mathrm{mg}$ TMB ( $\mathrm{ml} \geqslant 99.8 \%$ ethanol) $\left.)^{-1}\right] l^{-1}$. Hydrogen peroxide assays were incubated anaerobically for 7 days and then exposed to air under light-protected conditions at room temperature for $24 \mathrm{~h}$ and evaluated as described by Otero \& Nader-Macías (2006). Biochemical and enzyme profiles were determined with the API 20 A, Rapid ID $32 \mathrm{~A}$ and API ZYM kits (bioMérieux) according to the manufacturer's instructions. Inocula were prepared using anaerobic 24-h-old (API 20 A) or, in accordance with Dewhirst et al. (2001), 72-h-old (Rapid ID 32 A and API ZYM) cultures on blood agar. API $20 \mathrm{~A}$ tests were evaluated after $48 \mathrm{~h}$ of incubation. Growth on and fermentation of carbohydrates not included or with ambiguous results in API 20 A were analysed using anaerobic cultures in PY broth supplemented with $1 \%$ $(\mathrm{w} / \mathrm{v})$ inulin or $20 \mathrm{mM}$ raffinose and in UBM broth enriched with trypticase peptone and supplemented with $20 \mathrm{mM}$ D-fructose, D-xylose or $\alpha$-L-rhamnose or $10 \mathrm{mM}$ melibiose.

Production of short-chain volatile and non-volatile fatty acids and ammonium was analysed using anaerobic cultures in PYG broth and microaerobic cultures in URAS PYG broth. Meat extract was omitted for analysis of lactic acids. Volatile fatty acids were determined using GC analysis as described previously (Schäfer, 1995). Nonvolatile fatty acids were determined using HPLC analysis and (D- and L-lactic acid) /or (succinic acid) enzymic absorbance-based tests. HPLC analysis was carried out on an HP 1100 Series system (Agilent Technologies) equipped with a $150 \times 4.6 \mathrm{~mm}$ analytical column coated with $N, S$ dioctyl-D-penicillamine and a $4.0 \times 2.0 \mathrm{~mm}$ SecurityGuard C18 guard column (both from Phenomenex). The columns were operated at $35{ }^{\circ} \mathrm{C}$. The eluents were solutions of $\mathrm{CuSO}_{4}$ in (A) water $\left(0.5 \mathrm{mmol} \mathrm{l}^{-1}\right)$ and (B) water with $5 \%$ 2-propanol $\left(2.5 \mathrm{mmol} \mathrm{l}^{-1}\right)$ in a gradient mode $(0-35 \% \mathrm{~B}$ over $17 \mathrm{~min}, 35 \% \mathrm{~B}$ for $2 \mathrm{~min}, 35-100 \% \mathrm{~B}$ over $3 \mathrm{~min}$, $100 \%$ B for $1 \mathrm{~min}, 100-35 \%$ B over $1 \mathrm{~min}$ ) with a flow rate of $1.0 \mathrm{ml} \mathrm{min}{ }^{-1}$. The total injection volume for analysis was $20 \mu \mathrm{l}$ of $40 \%(\mathrm{v} / \mathrm{v})$ culture supernatant in eluent A. Compounds were detected by UV at $254 \mathrm{~nm}$ and identified by comparison against retention times using a lithium-DL-lactate standard (AppliChem). Chromeleon chromatography software (Dionex) was used for quantification. Enzymic absorbance-based tests (R-Biopharm) were applied according to the manufacturer's instructions using an Ultrospec 3300 pro UV/visible spectrophotometer (Amersham Biosciences) at $365 \mathrm{~nm}$. Ammonium was measured electrometrically using a DC218-NH4 ammonium electrode in combination with a SevenMulti S80 ion meter (both from Mettler Toledo). For analysis of cellular fatty acids, bacteria were grown anaerobically overnight in $100 \mathrm{ml} \mathrm{M} 2$ liquid medium. Saponification, fatty acid methylation and analysis of fatty acid methyl esters were carried out as described previously (Devillard et al., 2006). Three independent cultures, each grown in the same batch of M2, were always analysed for each strain. For some strains, the analysis was repeated using triplicate cultures in another, different batch of the medium (see Supplementary Table S2).

The results of phenotypic characterization are given in the species description. Phenotypic characteristics that serve to differentiate strains $\mathrm{A} 2$, lac15, lac16 and $\operatorname{lac} 31^{\mathrm{T}}$ from the type and reference strains of $O$. uli and O. profusa are given in Tables 1 and 2 and Supplementary Table S2. On the basis of the results of $16 \mathrm{~S}$ rRNA gene sequencing, DNADNA reassociation analyses and the differential phenotypic data, strains A2 [formerly named 'Olsenella (basonym Atopobium) oviles'], lac15, lac16 and $\operatorname{lac}^{2} 1^{\mathrm{T}}$ represent a novel species of the genus Olsenella, for which we propose the name Olsenella umbonata sp. nov. On the basis of the data from this study, we also propose emended descriptions of the genus Olsenella and the species Olsenella uli and Olsenella profusa.

\section{Emended description of the genus Olsenella Dewhirst et al. 2001}

The description remains as given by Dewhirst et al. (2001) with the following emendations. Cells are consistently or variably Gram-stain-positive. They occur singly, in pairs and in short to very long serpentine chains. Cells are microaerotolerantly (moderately obligately) anaerobic. Lactic acid is the major metabolic product from glucose. Minor products from glucose are formic and acetic acids. The cellular fatty acids consist mainly of saturated fatty acids. The major cellular fatty acid is variable, i.e. saturated unbranched or saturated branched. Found in the oral cavity and gastrointestinal tracts of humans, other mammals and probably of other homoeothermic vertebrates.

\section{Emended description of Olsenella uli (Olsen et al. 1991) Dewhirst et al. 2001}

The description remains as given by Dewhirst et al. (2001) with the following emendations. Cells are microaerotolerantly (moderately obligately) anaerobic (less than approx. $\left.5 \% \mathrm{O}_{2}, \mathrm{v} / \mathrm{v}\right)$. They are able to grow in microaerobic URAS 
Table 1. Differential phenotypic characteristics of strains lac15, lac16, lac $31^{\top}$ and $A 2$ and strains of $O$. uli and $O$. profusa

Strains: 1, strains lac15, lac16, lac31 $1^{\mathrm{T}}$ and A2; 2, O. uli DSM 7084 ${ }^{\mathrm{T}}$; 3, O. profusa DSM $13989^{\mathrm{T}}$, CCUG $45371^{\mathrm{T}}$ and CCUG $45372 .+$, Positive; - , negative; w, weak. Data were obtained in the present study.

\begin{tabular}{|c|c|c|c|}
\hline Characteristic & 1 & 2 & 3 \\
\hline \multicolumn{4}{|l|}{ Colony and cell morphology* } \\
\hline Diameter (FAA/PYG; mm) & $\leqslant 3-4 / 4$ & $\leqslant 2 / 2.5$ & $\leqslant 2 / 3$ \\
\hline Opacity (margin/centre) & Semi-translucent/opaque & Semi-translucent/opaque & Opaque/opaque \\
\hline Colour (margin/centre) & Grey/greyish white & Grey/greyish white & Cream-white/cream-white \\
\hline Texture & Butyrous & Butyrous & Granular \\
\hline Gram-stain variability & Marked & Slight & Slight \\
\hline \multicolumn{4}{|l|}{ Microaerobic growth in URAS PYG broth } \\
\hline Growth & Good & Negative to moderate & Negative to good \\
\hline Change in $\mathrm{OD}_{600}\left[\min . / \mathrm{mean} / \mathrm{max} .\left(t_{0}\right)\right] \dagger$ & $1.43 / 1.65 / 1.79(0.09)$ & 0/0.36/1.08 (0.04) & $0 / 1.29 / 1.56(0.04)$ \\
\hline Accumulation of hydrogen peroxide & - & - & $-/ \mathrm{w}$ \\
\hline
\end{tabular}

${ }^{*}$ On FAA and PYG agar after 7 days.

$\dagger$ Increase (minimum/mean/maximum) in $\mathrm{OD}_{600}$ after 4 days. For the maximal increase, the $\mathrm{OD}_{600}$ at $t_{0}$ is given in parentheses. Data are from three repetitions per strain.

PYG broth. The cellular fatty acids consist mainly of saturated unbranched fatty acids. The major cellular fatty acid of cells grown in M2 liquid medium is 18:0 (octadecanoic acid) (Supplementary Table S2 and Table 1). Additional phenotypic characteristics of the type strain O. uli DSM $7084^{\mathrm{T}}$ are given in Tables 1 and 2 .

\section{Emended description of Olsenella profusa Dewhirst et al. 2001}

The description remains as given by Dewhirst et al. (2001) with the following emendations. Cells are microaerotolerantly (moderately obligately) anaerobic (less than approx. $5 \% \mathrm{O}_{2}, \mathrm{v} / \mathrm{v}$ ). They are able to grow in microaerobic URAS PYG broth. The cellular fatty acids consist predominantly of saturated anteiso-branched fatty acids. The major cellular fatty acid of cells grown in M2 liquid medium is anteiso-14:0 (12-methyl-tetradecanoic acid) (Supplementary Table S2 and Table 1). Additional phenotypic characteristics of the type strain O. profusa DSM $13989^{\mathrm{T}}$ $\left(=\mathrm{CCUG} 45371^{\mathrm{T}}\right)$ and the reference strain CCUG 45372 are given in Tables 1 and 2 .

\section{Description of Olsenella umbonata sp. nov.}

Olsenella umbonata [um.bo.na'ta. N.L. fem. adj. umbonata bossed, umbonate (from L. masc. n. umbo, umbonis a shield boss), referring to the umbonate elevations of outgrown colonies on solid culture media].
Cells grown on FAA and PYG agar plates for $48 \mathrm{~h}$ under anaerobic conditions at $37{ }^{\circ} \mathrm{C}$ form colonies that are circular, up to $1.5 \mathrm{~mm}$ in diameter, have entire margins and smooth surfaces and are raised to slightly umbonate, semi-translucent, greyish-white and butyrous. Outgrown colonies on FAA and PYG agar display opaque, greyishwhite umbonate elevations (Table 1). No haemolysis occurs on FAA or blood agar. After anaerobic incubation on PGM, PGMM and PJMM agar plates at $37{ }^{\circ} \mathrm{C}$ for 14 days, colonies are circular, punctiform (PGMM) to $1 \mathrm{~mm}$ (PJMM) or $2 \mathrm{~mm}$ (PGM) in diameter, have entire margins and smooth surfaces and are flat (PGMM, PJMM) to slightly umbonate (PGM), translucent and butyrous. Cells grown under anaerobic conditions on PYG agar for $48 \mathrm{~h}$ and on PGM agar for 14 days are small [0.3-0.6 $\mu \mathrm{m}$ wide (mean, approx. $0.4 \mu \mathrm{m} ; n=78$ for PYG agar and $n=46$ for PGM agar) by $0.6-2.2 \mu \mathrm{m}$ long (mean, approx. $1.1 \mu \mathrm{m} ; n=62$ for PYG agar and $n=209$ for PGM agar)], irregular (centrally or terminally swollen) and occasionally curved rods (Supplementary Figs S2 and S3). Cells grown on PJMM agar are slightly shorter $(0.5-2.0 \mu \mathrm{m}$; mean, approx. $1.0 \mu \mathrm{m} ; n=40)$ and thus more often appear coccoid (Supplementary Fig. S4). Cells are variously arranged (Table 1). Very long, serpentine chains occur with cells grown for long periods on PGM agar (Supplementary Fig. S3). Cells are less (after $48 \mathrm{~h}$ ) or more (after 7 days) variably Gram-stain-positive (Table 1). Cells are non-motile and non-spore-forming. Cytochrome oxidase activity is not detected. Nitrate is not reduced. 
Table 2. Differential biochemical and enzyme characteristics of strains lac $15, \operatorname{lac} 16, \operatorname{lac} 31^{\top}$ and $A 2$ and strains of $O$. uli and $O$. profusa

Strains: 1 , strains lac15, lac16, lac31 ${ }^{\mathrm{T}}$ and A2; 2, O. uli DSM $7084^{\mathrm{T}} ; 3$, O. profusa strains DSM $13989^{\mathrm{T}}$ and CCUG $45371^{\mathrm{T}}$. + , Positive; - , negative; $\mathrm{V}$, variable. In Rapid ID $32 \mathrm{~A}$, all strains were negative for urease, $\alpha$-galactosidase, $\alpha$-arabinosidase, $\beta$-glucuronidase, raffinose fermentation, reduction of nitrates, indole production, pyroglutamic acid arylamidase, glutamic acid decarboxylase, $\alpha$-fucosidase and glutamyl glutamic acid arylamidase and positive for arginine dihydrolase, mannose fermentation, arginine arylamidase, proline arylamidase, leucyl glycine arylamidase, phenylalanine arylamidase, leucine arylamidase, tyrosine arylamidase, alanine arylamidase, glycine arylamidase, histidine arylamidase and serine arylamidase. In API $20 \mathrm{~A}$, all strains were negative for indole formation, urease and acidification of glycerol and melezitose and positive for acidification of glucose, gelatin hydrolysis (protease) and the Gram reaction. In API ZYM, all strains were negative for trypsin, $\alpha$-chymotrypsin, $\alpha$ galactosidase, $\beta$-glucuronidase, $\alpha$-mannosidase and $\alpha$-fucosidase. Values for API ZYM tests are means of the activity mark \pm SD $[n=20$ (column 1 ) or $n=5$ (columns 2 and 3)]. The activity mark is a measure of the amount of substrate hydrolysed (nmol), scored as follows: $0,<5 ; 1,5-<10 ; 2,10-$ $<20 ; 3,20-<30 ; 4,30-<40 ; 5, \geqslant 40$. Data were obtained in the present study unless indicated. API 20 A and API ZYM data were not reported by Olsen et al. (1991) or Dewhirst et al. (2001).

\begin{tabular}{|c|c|c|c|}
\hline Characteristic & 1 & 2 & 3 \\
\hline \multicolumn{4}{|l|}{ Rapid ID 32 A results } \\
\hline Profile & 2402073705 & $2012073705^{\star}$ & $2713473705^{\star}$ \\
\hline$\beta$-Galactosidase & - & - & + \\
\hline 6-Phospho- $\beta$-galactosidase & - & - & + \\
\hline$\alpha$-Glucosidase & + & - & + \\
\hline$\beta$-Glucosidase & - & + & + \\
\hline$N$-Acetyl- $\beta$-glucosaminidase & - & - & + \\
\hline Alkaline phosphatase & - & - & + \\
\hline \multicolumn{4}{|l|}{ API 20 A results } \\
\hline Profile & $441240(2 / 0) 2$ & 40060002 & 47776632 \\
\hline Aesculin hydrolysis ( $\beta$-glucosidase) & - & + & + \\
\hline \multicolumn{4}{|l|}{ Acidification of: } \\
\hline Mannitol & - & - & + \\
\hline Lactose & - & - & + \\
\hline Sucrose & + & $-{ }^{a_{\dagger}}$ & + \\
\hline Maltose & + & $-{ }^{a}$ & + \\
\hline Salicin & - & $-{ }^{a}$ & + \\
\hline Xylose & - & - & $+\ddagger$ \\
\hline Arabinose & - & - & + \\
\hline Cellobiose & - & - & + \\
\hline Mannose & + & $-{ }^{a}$ & + \\
\hline Raffinose & - & - & + \\
\hline Sorbitol & - & - & $+末$ \\
\hline Rhamnose & - & - & $+{ }^{b}$ \\
\hline Trehalose & $\mathrm{v}(+) \S$ & - & + \\
\hline \multicolumn{4}{|l|}{ Other test } \\
\hline Fermentation of melibiose & - & -11 & +11 \\
\hline \multicolumn{4}{|l|}{ API ZYM results } \\
\hline Alkaline phosphatase & $0.7 \pm 0.5$ & $1.8 \pm 0.4$ & $2.4 \pm 0.5$ \\
\hline Esterase $(\mathrm{C} 4)$ & $2.3 \pm 0.4$ & $1.2 \pm 0.4$ & $1.4 \pm 0.5$ \\
\hline Esterase lipase (C8) & $1.8 \pm 0.4$ & $1.2 \pm 0.4$ & $1.2 \pm 0.4$ \\
\hline Lipase (C14) & $0.6 \pm 0.5$ & $0.0 \pm 0.0$ & $1.0 \pm 0.0$ \\
\hline Leucine arylamidase & $3.7 \pm 0.5$ & $3.2 \pm 0.4$ & $3.4 \pm 0.5$ \\
\hline Valine arylamidase & $1.9 \pm 0.4$ & $1.4 \pm 0.5$ & $3.2 \pm 0.4$ \\
\hline Cystine arylamidase & $0.8 \pm 0.4$ & $0.6 \pm 0.5$ & $2.4 \pm 0.5$ \\
\hline Acid phosphatase & $3.5 \pm 0.7$ & $3.6 \pm 0.5$ & $3.2 \pm 0.4$ \\
\hline Naphthol-AS-BI-phosphohydrolase & $2.3 \pm 0.4$ & $2.2 \pm 0.4$ & $4.2 \pm 0.4$ \\
\hline$\beta$-Galactosidase & $0.0 \pm 0.0$ & $0.0 \pm 0.0$ & $0.4 \pm 0.5$ \\
\hline$\alpha$-Glucosidase & $4.2 \pm 0.8$ & $0.0 \pm 0.0$ & $1.0 \pm 0.0$ \\
\hline$\beta$-Glucosidase & $0.0 \pm 0.0$ & $3.0 \pm 0.0$ & $0.0 \pm 0.0$ \\
\hline$N$-Acetyl- $\beta$-glucosaminidase & $0.0 \pm 0.0$ & $0.0 \pm 0.0$ & $0.2 \pm 0.4$ \\
\hline
\end{tabular}

*Profiles reported by Dewhirst et al. (2001) were 2012033705 (one reaction different from the present result) for O. uli and 4516053705 (seven reactions different) for $O$. profusa. 
$\dagger$ Different from result reported by: $a$, Olsen et al. (1991); $b$, Dewhirst et al. (2001). In these studies, results were determined using the methods of Holdeman et al. (1977).

\$Not determined by Dewhirst et al. (2001).

\$Three of four strains, including the type strain, tested positive.

IIData taken from Olsen et al. (1991) (O. uli) and Dewhirst et al. (2001) (O. profusa).

Cells are microaerotolerantly (moderately obligately) anaerobic (less than approx. $5 \% \mathrm{O}_{2}, \mathrm{v} / \mathrm{v}$ ). They grow routinely in microaerobic URAS PYG broth (Table 1). During growth, the resazurin in URAS PYG broth is reduced (colour change of the medium from red to orange). Cells are mesophilic; growth is absent at $21{ }^{\circ} \mathrm{C}$, moderately good at $30{ }^{\circ} \mathrm{C}$, very good at $37^{\circ} \mathrm{C}$ and good at $45{ }^{\circ} \mathrm{C}$. Cells are neutrophilic and acidotolerant; the $\mathrm{pH}$ range for growth is 4.5-8.0, occasionally $\mathrm{pH} 8.5$ (optimum, pH 6.0-7.0). Growth is positive in $20 \%$ bile and is absent in $6.5 \% \mathrm{NaCl}$. Growth is stimulated markedly by $0.1 \%$ Tween 80 and is not stimulated by $0.5 \%$ L-arginine. Hydrogen sulfide is not produced from meat peptone or L-cysteine. No gas is detected in agar deeps. Hydrogen peroxide is not accumulated. Catalase activity is negative. Biochemical and enzyme characteristics using API kits are listed in Table 2. In API $20 \mathrm{~A}$, acidification of trehalose is variable (negative for strain A2). Growth on and fermentation of D-fructose is positive. Growth on and fermentation of melibiose (Table 2), inulin, raffinose, $\alpha$-L-rhamnose and $\mathrm{D}$-xylose is negative. Cells are able to grow on mucin from porcine stomach (Table 1). Under anaerobic conditions, glucose is metabolized predominantly to D-lactic acid (mean, approx. $39 \mathrm{mmol} \mathrm{l}^{-1}$ ) and to minor amounts of formic acid (mean, approx. $4.5 \mathrm{mmol}^{-1}$ ) and acetic acid (mean, approx. $\left.3.3 \mathrm{mmol}^{-1}\right)(n=12)$. Under unreduced microaerobic conditions, metabolism of glucose is not decreased in terms of production of D-lactic acid (mean, approx. $\left.39 \mathrm{mmol} \mathrm{l}^{-1} ; n=10\right)$ and is decreased slightly in terms of production of formic and acetic acids [means, approx. 2.5 and $2.2 \mathrm{mmol}^{-1}$, respectively $\left.(n=12)\right]$. Glucose is not metabolized to L-lactic acid, propionic acid, butyric acid, isobutyric acid, valeric acid, isovaleric acid, caproic acid or succinic acid. Cells are presumably obligately homofermentative and produce formic and acetic acids via the anaerobic pyruvate-formate lyase system (Axelsson, 2004). Lactic and formic acids are reducing agents and contribute to the oxygen tolerance of cells (Brioukhanov \& Netrusov, 2007). Ammonium is produced from peptone under anaerobic and unreduced microaerobic conditions [means, approx. 12 and $9 \mathrm{mmol} \mathrm{l}^{-1}$, respectively $(n=12)$ ]. Cellular fatty acids consist predominantly of saturated unbranched fatty acids. The major cellular fatty acids of cells grown in M2 liquid medium are the saturated acids 14:0 (tetradecanoic acid) and 18:0 (octadecanoic acid) in varying proportions (Supplementary Table S2 and Table 1). Well-adapted and presumably indigenous to the gastrointestinal tract of homoeothermic vertebrates, as suggested by the phenotypic characteristics of mesophily, obligate anaerobiosis and microaerotolerance [appropriate to the micro-oxic conditions at the absorptive mucosae (Isolauri et al., 2004; Wilson, 2005)], neutrophily and acidotolerance, bile resistance and mucin utilization.

The type strain, lac $31^{\mathrm{T}}\left(=\right.$ CCUG $58604^{\mathrm{T}}=$ DSM $22620^{\mathrm{T}}$ $=\mathrm{JCM} 16156^{\mathrm{T}}$ ), was isolated from the mucosal jejunum of a pig in Berlin, Germany. Strain A2 (=CCUG 58212 $=$ DSM $22619=J C M$ 16157) was isolated from the ruminal fluid of a sheep in Aberdeen, UK. Strain A2 can be readily differentiated from the type strain by a negative result for acidification of trehalose in the API 20 A strip. Strains lac15 and lac16, isolated together with the type strain, are also included in the species.

\section{Acknowledgements}

We gratefully acknowledge the technical help and expertise of Sabine Schmidt (Department of Gastrointestinal Microbiology, German Institute of Human Nutrition Potsdam-Rehbrücke) (VITEK ANI), Sybille Dehler (Eurofins MWG Operon) (primer-walking sequencing), Verena Eckert-Funke (Institute of Veterinary Anatomy, Free University Berlin) (electron microscopy), Marita Eitinger, Anett Kriesten and Ute Reinhardt (Institute of Animal Nutrition) (short-chain fatty acids and ammonium) and David Brown, Donna Henderson and Nest McKain (Rowett Institute of Nutrition and Health) (cellular fatty acids). We thank W. W. Christie for help in identifying fatty acid methyl esters and C. Kreuzwieser and C. Koch (Institute of Greek and Latin Philology, Free University Berlin) for help regarding the etymology of the species epithet. The Rowett Institute of Nutrition and Health receives funding from the Scottish Executive Environmental and Rural Affairs Department. L. S. is partly supported by The Health \& Medical Care Committee of the Region Västra Götaland, Sweden. M. K. received doctoral stipends according to the Berlin Law for the Promotion of Young Scientists (Nachwuchsförderungsgesetz) and from the Institute of Animal Nutrition; she sincerely thanks Ortwin Simon and David Taras for their support of this work.

\section{References}

Achtman, M. \& Wagner, M. (2008). Microbial diversity and the genetic nature of microbial species. Nat Rev Microbiol 6, 431-440.

Axelsson, L. (2004). Lactic acid bacteria: classification and physiology. In Lactic Acid Bacteria: Microbiological and Functional Aspects, 3rd edn, pp. 1-66. Edited by S. Salminen, A. von Wright \& A. Ouwehand. New York: Marcel Dekker.

Bahrani-Mougeot, F. K., Paster, B. J., Coleman, S., Ashar, J., Barbuto, S. \& Lockhart, P. B. (2008). Diverse and novel oral bacterial species in blood following dental procedures. J Clin Microbiol 46, 2129-2132.

Bowman, K. S., Moe, W. M., Rash, B. A., Bae, H. S. \& Rainey, F. A. (2006). Bacterial diversity of an acidic Louisiana groundwater contaminated by dense nonaqueous-phase liquid containing chloroethanes and other solvents. FEMS Microbiol Ecol 58, 120-133.

Brioukhanov, A. L. \& Netrusov, A. I. (2007). Aerotolerance of strictly anaerobic microorganisms and factors of defense against oxidative stress: a review. Appl Biochem Microbiol 43, 567-582. 
Chhour, K. L., Hinds, L. A., Deane, E. M. \& Jacques, N. A. (2008). The microbiome of the cloacal openings of the urogenital and anal tracts of the tammar wallaby, Macropus eugenii. Microbiology 154, 15351543.

Cho, S. J., Cho, K. M., Shin, E. C., Lim, W. J., Hong, S. Y., Choi, B. R., Kang, J. M., Lee, S. M., Kim, Y. H. \& other authors (2006). 16S rDNA analysis of bacterial diversity in three fractions of cow rumen. J Microbiol Biotechnol 16, 92-101.

Cole, J. R., Wang, Q., Cardenas, E., Fish, J., Chai, B., Farris, R. J., Kulam-Syed-Mohideen, A. S., McGarrell, D. M., Marsh, T. \& other authors (2009). The Ribosomal Database Project: improved alignments and new tools for rRNA analysis. Nucleic Acids Res 37, D141D145.

Devillard, E., McIntosh, F. M., Newbold, C. J. \& Wallace, R. J. (2006). Rumen ciliate protozoa contain high concentrations of conjugated linoleic acids and vaccenic acid, yet do not hydrogenate linoleic acid or desaturate stearic acid. Br J Nutr 96, 697-704.

Dewhirst, F. E., Paster, B. J., Tzellas, N., Coleman, B., Downes, J., Spratt, D. A. \& Wade, W. G. (2001). Characterization of novel human oral isolates and cloned $16 \mathrm{~S}$ rDNA sequences that fall in the family Coriobacteriaceae: description of Olsenella gen. nov., reclassification of Lactobacillus uli as Olsenella uli comb. nov. and description of Olsenella profusa sp. nov. Int J Syst Evol Microbiol 51, 1797-1804.

Dowd, S. E., Sun, Y., Wolcott, R. D., Domingo, A. \& Carroll, J. A. (2008). Bacterial tag-encoded FLX amplicon pyrosequencing (bTEFAP) for microbiome studies: bacterial diversity in the ileum of newly weaned Salmonella-infected pigs. Foodborne Pathog Dis 5, 459-472.

Eschenlauer, S. C. P., McKain, N., Walker, N. D., McEwan, N. R., Newbold, C. J. \& Wallace, R. J. (2002). Ammonia production by ruminal microorganisms and enumeration, isolation, and characterization of bacteria capable of growth on peptides and amino acids from the sheep rumen. Appl Environ Microbiol 68, 4925-4931.

Felsenstein, J. (1985). Confidence limits on phylogenies: an approach using the bootstrap. Evolution 39, 783-791.

Felsenstein, J. (2010). PHYLIP (Phylogeny Inference Package), version 3.69. Distributed by the author. Department of Genome Sciences, University of Washington, Seattle, USA.

Fitch, W. M. (1971). Toward defining course of evolution: minimum change for a specific tree topology. Syst Zool 20, 406-416.

Hernandez, J. D., Scott, P. T., Shephard, R. W. \& Al Jassim, R. A. M. (2008). The characterization of lactic acid producing bacteria from the rumen of dairy cattle grazing on improved pasture supplemented with wheat and barley grain. J Appl Microbiol 104, 1754-1763.

Hobson, P. N. (1969). Rumen bacteria. Methods Microbiol 3B, $133-$ 149.

Holdeman, L. V., Cato, E. P. \& Moore, W. E. C. (1977). Anaerobe Laboratory Manual, 4th edn. Blacksburg, VA: Virginia Polytechnic Institute and State University.

Hooper, S. J., Crean, S. J., Lewis, M. A. O., Spratt, D. A., Wade, W. G. \& Wilson, M. J. (2006). Viable bacteria present within oral squamous cell carcinoma tissue. J Clin Microbiol 44, 1719-1725.

Inês, A., Tenreiro, T., Tenreiro, R. \& Mendes-Faia, A. (2008). [Wine lactic acid bacteria - Part I]. Cienc Tec Vitivinic 23, 81-96 (in Portuguese).

Isolauri, E., Salminen, S. \& Ouwehand, A. C. (2004). Probiotics. Best Pract Res Clin Gastroenterol 18, 299-313.

Johnson, M., Zaretskaya, I., Raytselis, Y., Merezhuk, Y., McGinnis, S. \& Madden, T. L. (2008). NCBI BLAST: a better web interface. Nucleic Acids Res 36, W5-W9.

Jousimies-Somer, H., Summanen, P., Citron, D. M., Baron, E. J., Wexler, H. M. \& Finegold, S. M. (2002). Wadsworth-KTL Anaerobic Bacteriology Manual, 6th edn. Belmont, CA: Star Publishing.
Juárez Tomás, M. S., Otero, M. C., Ocaña, V. \& Nader-Macias, M. E. (2004). Production of antimicrobial substances by lactic acid bacteria. I. Determination of hydrogen peroxide. Methods Mol Biol 268, 337346.

Karakashev, D., Galabova, D. \& Simeonov, I. (2003). A simple and rapid test for differentiation of aerobic from anaerobic bacteria. World J Microbiol Biotechnol 19, 233-238.

Khachatryan, Z. A., Ktsoyan, Z. A., Manukyan, G. P., Kelly, D., Ghazaryan, K. A. \& Aminov, R. I. (2008). Predominant role of host genetics in controlling the composition of gut microbiota. PLOS ONE 3, e3064.

Kraatz, M. \& Taras, D. (2008). Veillonella magna sp. nov., isolated from the jejunal mucosa of a healthy pig, and emended description of Veillonella ratti. Int J Syst Evol Microbiol 58, 2755-2761.

Krogius-Kurikka, L., Kassinen, A., Paulin, L., Corander, J., Mäkivuokko, H., Tuimala, J. \& Palva, A. (2009). Sequence analysis of percent $\mathrm{G}+\mathrm{C}$ fraction libraries of human faecal bacterial DNA reveals a high number of Actinobacteria. BMC Microbiol 9, 68.

Lau, S. K. P., Woo, P. C. Y., Fung, A. M. Y., Chan, K.-M., Woo, G. K. S. \& Yuen, K.-Y. (2004). Anaerobic, non-sporulating, Gram-positive bacilli bacteraemia characterized by $16 \mathrm{~S}$ rRNA gene sequencing. $J$ Med Microbiol 53, 1247-1253.

Leser, T. D., Amenuvor, J. Z., Jensen, T. K., Lindecrona, R. H., Boye, M. \& Møller, K. (2002). Culture-independent analysis of gut bacteria: the pig gastrointestinal tract microbiota revisited. Appl Environ Microbiol 68, 673-690.

Lu, J. R., Idris, U., Harmon, B., Hofacre, C., Maurer, J. J. \& Lee, M. D. (2003). Diversity and succession of the intestinal bacterial community of the maturing broiler chicken. Appl Environ Microbiol 69, 68166824 .

Martinez-Medina, M., Aldeguer, X., Gonzalez-Huix, F., Acero, D. \& Garcia-Gil, L. J. (2006). Abnormal microbiota composition in the ileocolonic mucosa of Crohn's disease patients as revealed by polymerase chain reaction-denaturing gradient gel electrophoresis. Inflamm Bowel Dis 12, 1136-1145.

Munson, M. A., Pitt-Ford, T., Chong, B., Weightman, A. \& Wade, W. G. (2002). Molecular and cultural analysis of the microflora associated with endodontic infections. J Dent Res 81, 761-766.

Munson, M. A., Banerjee, A., Watson, T. F. \& Wade, W. G. (2004). Molecular analysis of the microflora associated with dental caries. J Clin Microbiol 42, 3023-3029.

Olsen, I., Johnson, J. L., Moore, L. V. H. \& Moore, W. E. C. (1991). Lactobacillus uli sp. nov. and Lactobacillus rimae sp. nov. from the human gingival crevice and emended descriptions of Lactobacillus minutus and Streptococcus parvulus. Int J Syst Bacteriol 41, 261-266.

Orla-Jensen, S. (1919). The Lactic Acid Bacteria. Copenhagen: Høst \& Son.

Otero, M. C. \& Nader-Macías, M. E. (2006). Inhibition of Staphylococcus aureus by $\mathrm{H}_{2} \mathrm{O}_{2}$-producing Lactobacillus gasseri isolated from the vaginal tract of cattle. Anim Reprod Sci 96, 3546.

Ozutsumi, Y., Tajima, K., Takenaka, A. \& Itabashi, H. (2005). The effect of protozoa on the composition of rumen bacteria in cattle using 16S rRNA gene clone libraries. Biosci Biotechnol Biochem 69, 499-506.

Rivière, D., Desvignes, V., Pelletier, E., Chaussonnerie, S., Guermazi, S., Weissenbach, J., Li, T., Camacho, P. \& Sghir, A. (2009). Towards the definition of a core of microorganisms involved in anaerobic digestion of sludge. ISME J 3, 700-714.

Rzhetsky, A. \& Nei, M. (1992). A simple method for estimating and testing minimum-evolution trees. Mol Biol Evol 9, 945-967. 
Saitou, N. \& Nei, M. (1987). The neighbor-joining method: a new method for reconstructing phylogenetic trees. Mol Biol Evol 4, 406425.

Schäfer, K. (1995). Analysis of short-chain fatty acids from different intestinal samples by capillary gas chromatography. Chromatographia 40, 550-556.

Smibert, R. M. \& Krieg, N. R. (1994). Phenotypic characterization. In Methods for General and Molecular Bacteriology, pp. 607-653. Edited by P. Gerhardt, R. G. E. Murray, W. A. Wood \& N. R. Krieg. Washington, DC: American Society for Microbiology.

Stackebrandt, E., Frederiksen, W., Garrity, G. M., Grimont, P. A. D., Kämpfer, P., Maiden, M. C. J., Nesme, X., Rosselló-Mora, R., Swings, J. \& other authors (2002). Report of the ad hoc committee for the reevaluation of the species definition in bacteriology. Int J Syst Evol Microbiol 52, 1043-1047.

Tajima, K., Arai, S., Ogata, K., Nagamine, T., Matsui, H., Nakamura, M., Aminov, R. I. \& Benno, Y. (2000). Rumen bacterial community transition during adaptation to high-grain diet. Anaerobe 6, 273-284.

Tamura, K. \& Nei, M. (1993). Estimation of the number of nucleotide substitutions in the control region of mitochondrial DNA in humans and chimpanzees. Mol Biol Evol 10, 512-526.

Tamura, K., Nei, M. \& Kumar, S. (2004). Prospects for inferring very large phylogenies by using the neighbor-joining method. Proc Natl Acad Sci U S A 101, 11030-11035.

Tamura, K., Dudley, J., Nei, M. \& Kumar, S. (2007). MEGA4: molecular evolutionary genetics analysis (MEGA) software version 4.0. Mol Biol Evol 24, 1596-1599.

Thompson, J. D., Higgins, D. G. \& Gibson, T. J. (1994). CLUSTAL W: improving the sensitivity of progressive multiple sequence alignment through sequence weighting, position-specific gap penalties and weight matrix choice. Nucleic Acids Res 22, 4673-4680.
Tsukahara, T. \& Ushida, K. (2002). Succinate accumulation in pig large intestine during antibiotic-associated diarrhea and the constitution of succinate-producing flora. J Gen Appl Microbiol 48, 143154.

Urdiain, M., López-López, A., Gonzalo, C., Busse, H.-J., Langer, S., Kämpfer, P. \& Rosselló-Móra, R. (2008). Reclassification of Rhodobium marinum and Rhodobium pfennigii as Afifella marina gen. nov. comb. nov. and Afifella pfennigii comb. nov., a new genus of photoheterotrophic Alphaproteobacteria and emended descriptions of Rhodobium, Rhodobium orientis and Rhodobium gokarnense. Syst Appl Microbiol 31, 339-351.

Wayne, L. G., Brenner, D. J., Colwell, R. R., Grimont, P. A. D., Kandler, O., Krichevsky, M. I., Moore, L. H., Moore, W. E. C., Murray, R. G. E. \& other authors (1987). Report of the ad hoc committee on reconciliation of approaches to bacterial systematics. Int $J$ Syst Bacteriol 37, 463-464.

Weiss, A., Jérôme, V., Freitag, R. \& Mayer, H. K. (2008). Diversity of the resident microbiota in a thermophilic municipal biogas plant. Appl Microbiol Biotechnol 81, 163-173.

Wilson, M. (2005). The gastrointestinal tract and its indigenous microbiota. In Microbial Inhabitants of Humans: their Ecology and Role in Health and Disease, pp. 251-317. Cambridge: Cambridge University Press.

Winn, W. C., Jr, Allen, S. D., Janda, W. M., Koneman, E. W., Procop, G. W., Schreckenberger, P. C. \& Woods, G. L. (2006). The anaerobic bacteria. In Koneman's Color Atlas and Textbook of Diagnostic Microbiology, 6th edn, pp. 877-944. Baltimore: Lippincott Williams $\&$ Wilkins.

Wongtanet, J., Sang, B.-I., Lee, S.-M. \& Pak, D. (2007). Biohydrogen production by fermentative process in continuous stirred-tank reactor. Int J Green Energy 4, 385-395. 